\title{
Conceptions of Authorship
}

\section{The Case of Ármanns rímur and Their Reworkings in Early Modern Iceland}

\begin{abstract}
Since the early $20^{\text {th }}$ century, Eiríkur Laxdal's Ólandssaga (ca. 1820?) has been treated as one of Iceland's first novels, which was not always the case. Eiríkur's contemporaries already noticed that he borrowed from existing (folk?) stories and integrated them into his own narrative. This realisation soon led to the assumption that Ólandssaga was a folklore collection rather than a work composed by one individual. Among the texts Eirikur is proven to have borrowed from, there is the story of Ármann and Dorsteinn, which survives in several rímur cycles and two sagas. Ólandssaga incorporates not just one but all versions of the story. In this chapter, I trace the rise of the author in Early Modern Iceland by studying Ármanns rímur and their reworkings against the background of contemporary discussions of their origin and authorship.
\end{abstract}

Keywords

Intertextuality, Manuscripts, Folk Tales, Romance, rímur, Saga, Icelandic Novel, Novelisation

\section{Introduction}

Sveipaði hann pví öllu um sig og í kringum sig og gekk pannig til að sofa. Og varð pó ekki svefnsamt pví að bæði var í honum kvíði og hræðsla. Par með pjáði hann sultur og matleysi. Sagði hann við sjálfan sig að betra mundi að hressa sig við og gjöra sér nokkuð til skemmtunar. Tók hann pá til að kveða kvæði, drápur og flokka. Dví að hann kunni allmargt par af. En pegar hann lyktaði hvert kvæði heyrði hann raustu nokkra sem sagði nú er mér skemmt ekki vissi hann hvort raustin var innarlega eða framarlega uppi eður niðri. Hélt hann áfram með kveðskapinn og dró smám saman frá honum hræðslan svo hann varð æ hughraustari uns að honum sé pungi mikill svo hann gat sér ekki lengur uppi haldið og lagðist pví til svefnværðar hraustari en vonir stóðu til. ${ }^{1}$

He covered everything around him and like that went to bed. But he could not sleep because he was filled with both sorrow and fear. In addition, he suffered from hunger and the lack of food. So, he said to himself that it would be better to cheer himself up and do something for his own amusement. He then started to chant kvœeði, drápur, and flokka since he knew a good many of them. But after finishing each poem, he heard a voice say: "Now I am entertained." He did not know whether the voice came from inside or outside, from above or below. He continued with the poetry and his fear

1 Eiríkur Laxdal: Ólandssaga, p. 132. Punctuation according to Lbs 554 4to. Eiríkur Laxdal: Ólandssaga, [ca. 1820?], fol. 36v-37r. All translations are my own, unless stated otherwise. 
steadily decreased, so that he became braver and braver until he felt very drowsy, so that he could no longer keep himself up and therefore lay down for his night's rest, braver than it was to be expected.

When Porsteinn is sent away to find his father's lost sheep but instead discovers his brothers' dead bodies in a cave, it is poetry that gives him comfort in this time of desperation. And as a reward for the entertainment he thus inadvertently provides, a man called Ármann, overhearing his declamation, promises Porsteinn to support him through his suffering and the trials that will follow: in ólandssaga, it evidently pays off to have some knowledge of poetry. This passage is a narrative on narration, a self-referential scene that illustrates the act of reciting literature and its potential purposes. One could even interpret this scene in ólandssaga with reference to biographical details of the Icelandic author Eiríkur Laxdal Eiríksson: living as a vagrant in his final years following the loss of his farmstead, Eiríkur Laxdal probably made a living from reading his own stories and poems and those of others during kvöldvaka ('evening wake').

ólandssaga borrows from numerous sagas and rimur (i.e. poetic narratives), such as the narrative about Ármann and Dorsteinn in the example just discussed. These links again hint at the importance of having some knowledge of poetry and literature, in accordance with principles of Icelandic literary tradition. Pre-modern Icelandic literature, similar to other European literatures of that time, is explicitly intertextual: a secondary character of one saga is the protagonist of another, tying both texts together; sagas are turned into rimur and vice versa; older narratives are reworked into newer versions. It is particularly noteworthy that these practices are present primarily in post- $16^{\text {th }}$-century manuscripts, although print had already found its way to Iceland at this point. In fact, due to the advent of paper as a new writing material, which was more affordable than vellum, Icelandic manuscript culture flourished and did not come to an end until the $20^{\text {th }}$ century. ${ }^{3}$ Moreover, the printing press was in the hands of the Church from the very beginning, resulting in a mostly ecclesiastical printing culture. No secular press was authorised until the printing press on the island of Hrappsey in Western Iceland began operations in $1773 .{ }^{4}$

This chapter does not aim to trace to what extent Eiríkur Laxdal might have written himself into ólandssaga, but to examine conceptions of authorship in Iceland, based on a discussion of "Langfeðgapáttur" ('story of bloodline'), an episode of several chapters in ólandssaga, and the different tales of Ármann and Porsteinn it draws on. All these texts share the same subject matter, but they differ with respect to form (prose versus poetry), materiality, and paratextual features, particularly those which refer to the author (attributed in the manuscript, print, or externally). Especially where the reception of these

2 E.g. Lbs 2370 II 4to. Sighvatur Grímsson Borgfirðingur: Prestaævir á Íslandi. XIII. Bindi: Húnavatnsprófastsdæmi, 1900-1929.

3 Driscoll 2013, p. 52; Margrét Eggertsdóttir 2006, p. 176.

4 Jón Helgason 1928, p. 15. 
poetic and prose texts is concerned, the differences have implications for the conception of authorship: the growing scholarly interest in saga traditions instigated during the European Enlightenment by the Icelandic manuscript collector Árni Magnússon led to a re-evaluation of the relationship between author and text. These developments were also in part a response to the question of how to treat these contemporary prose texts, whose authors were sometimes known. The analysis of metatextual commentaries on ólandssaga and its hypotexts about Ármann and Dorsteinn will show that authorship is closely linked to the text itself: the reading and meaning of a text changes depending on the reader's expectations of the text, often influenced by a specific concept of authorship as well as by contextual information. Vice versa, the author is deduced and constructed from a distinct reading of a text. ${ }^{5}$ As a literary palimpsest with unmarked quotations, ólandssaga especially led to confusion among $19^{\text {th }}$ - and $20^{\text {th }}$-century scholars in the field of folklore studies. ${ }^{6}$ Was it to be treated as a folk tale collection and, if so, how was its loose adaption of older tales like Ármanns rímur by Jón leerði Guðmundsson to be dealt with?

\section{Transmission and Transformation of Ármanns rímur}

The text usually referred to as Ármanns rímur is an epic poem composed by Jón laerð̃i Guðmundsson in 1637. In eight rímur, it tells the story of porsteinn, an idle good-fornothing, and Ármann, a spirit-like man, who helps him survive the trials he must face throughout the story. There are four extant copies of the rimur. Three of them date back to the $17^{\text {th }}$ century, having been compiled by Árni Magnússon. ${ }^{7}$ The fourth copy was written in the late 1760 s, indicating that Ármanns rímur were still circulating in $18^{\text {th }}$-century Iceland. ${ }^{8}$ In the late $17^{\text {th }}$ century, the poetical narrative had already been turned into a saga by Jón sýslumađur porláksson, ${ }^{9}$ which is preserved in four manuscripts: Árni Magnússon's copy ( $17^{\text {th }}$ century) ${ }^{10}$ a copy commissioned by his contemporary Magnús Jónsson í Vigur (1693-1696, probably related to Árni's copy), ${ }^{11}$ and two copies from the

5 Genette 1997.

6 E.g. Jón Árnason 1954; Einar Ólafur Sveinsson 1929; Einar Ólafur Sveinsson 1940.

7 AM 128 I-III 8vo. Jón loerði Guðmundsson: Rímur af Ármanni, [ca. 1700]. An overview of the manuscripts and the transmission of the text is given in Jón Helgason 1948, pp. XXII-XXV. Also Stegmann 2017, p. [429].

8 Lbs 896 4to. Jón leerði Guðmundsson: Rímur af Ármanni, [late 1760s].

9 On a paper slip in AM 128 I 8vo, Árni Magnússon writes that Jón Porláksson (the author of the prose narrative based on the rimur) sent him the manuscript in 1701. It is possible that this version of the rímur served him as a model for composing the saga.

10 AM 551 d alfa 4to. Compilation of sagas, including Jón Porláksson's Ármanns saga og Porsteins gála, [17 ${ }^{\text {th }}$ century]. See Stegmann 2017, p. [395].

11 BL Add. 4859 fol. Sagna Flockur Wtlendscra pioda [...], [1693-1696]. According to NKS 18364 to (Árni Magnússon: Qvædam Excerpta de Monumentis et Historiis Islandicis et eorum Auctoritate, [mid- 
$18^{\text {th }}$ century. ${ }^{12}$ There are, however, no copies extant from the $19^{\text {th }}$ century, even though Icelanders were at that time still very eager to copy manuscripts. ${ }^{13}$ The decreased interest in Jón Porláksson's Ármanns saga is probably due to the existence of a newer version of the same subject matter, which was printed in the 1780s in Hrappsey, ${ }^{14}$ replacing the older narrative of Ármann and porsteinn. Numerous handwritten copies - the earliest dating to $1795 / 1796$, the latest to $1897^{15}$ - as well as a reprint in Akureyri in $1858^{16}$ show that this reworked tale was quite popular and found wide circulation.

\section{3. Ármanns páttr gamli and the Question of Origin}

One of the first scholars to study the older material was the Icelandic manuscript collector Árni Magnússon. ${ }^{17}$ Manuscript NKS 1836 4to, which includes copies of notes by Árni on collected texts, contains a paragraph on Jón Porláksson's Ármanns saga:

Sỏguna af Armanni og porsteini Gála hefi eg fengid frá Joni Porlákssyni syslumanni i Austfiỏrdum, og hana sídan communicerad Magnusi Jonssyni i Wigur, svo at vonlegt er, ad hún á Islandi dreifast muni. Nefndan Sỏgupátt hefur Jon porlaksson sealfur componerad i prosam efter Ármanns Rímum Jons lærda, og hefur Jon siálfur petta fyrer mer medkent. ${ }^{18}$

I received Sagan af Ármanni og Porsteini Gála from Jón Porláksson who is sýslumaður in the Eastfjords, and I then passed it on to Magnús Jónsson í Vigur, so it is to be expected that it circulates

$18^{\text {th }}$ century], pp. 17f.), Árni Magnússon passed Jón Porláksson's Ármanns saga on to Magnús Jónsson í Vigur, assuming that the saga would be circulating in Iceland. Jón Helgason (1948, p. XXVIXXVIII) did not know of any copies. However, BL Add. 4859 fol., commissioned by Magnús Jónsson í Vigur, contains a copy of the saga that possibly goes back to Árni's manuscript. BL Add. 4859 fol. was later sold to the British Museum London, probably by Sir Joseph Banks in the late $18^{\text {th }}$ century (Seidel 2014, pp. 78-80).

12 ÍB 45 fol. Compilation of sagas, including Jón Porláksson's Ármanns saga og porsteins gála, [1735]; Lbs 633 fol. Saman safn af Islendskumm Nordskumm [...], 1760. Lbs 633 fol. probably goes back to BL Add. 4859 fol.: they share eight sagas, including two illustrations in Kirjalax saga.

13 E.g. Driscoll 1997 about Jón Hjaltalín or Driscoll 2012 about Magnús Jónsson í Tjaldanesi.

14 Ármanns saga [1782?].

15 AM 934 4to; ÍB 76 4to; ÍB 210 4to; ÍB 230 4to; ÍB 307 4to; JS 270 8vo; Lbs 261 8vo; Lbs 1461 4to; Lbs 1756 8vo; Lbs 1785 4to; Lbs 2330 4to; Lbs 3170 4to; Lbs 3910 8vo; Lbs 3946 8vo; Lbs 3627 4to (Ármanns saga is only mentioned in both tables of contents, fol. $1 \mathrm{v}$ and 75r); Lbs 3972 8vo; Lbs 4364 8vo; Lbs 4655 4to.

16 Ármanns saga 1858.

17 Stegmann 2017; Stegmann 2018.

18 NKS 1836 4to. Árni Magnússon: Qvædam Excerpta de Monumentis et Historiis Islandicis et eorum Auctoritate, [mid-18 ${ }^{\text {th }}$ century], pp. 17f. as cited in Jón Helgason 1948, p. XXVI; Jón Helgason 1980, p. 40. 
in Iceland. Said sögupáttur, Jón Porláksson composed in prose by himself based on Ármanns rímur by Jón leerđi, and Jón himself confessed this to me.

AM 551 d alfa 4to, Árni's copy of the saga, contains a glued-on note slip saying "Imposturæ J. Th. S.”, meant as a hint that Jón Porláksson's text was a contemporary 'forgery' and should not be considered an older, authentic narrative. ${ }^{19}$ This opinion is echoed later in an index for Árni's manuscript collection prepared by Jón ólafsson úr Grunnavík, where he described Jón Porláksson as a person who liked to 'compose' ("dikta upp") sagas and therefore "fabricated' ("laug upp") seven poettir, which Jón Ólafsson also referred to as imposturce. ${ }^{20}$ Interestingly, there is no such remark about Jón loerði, the author of Ármanns rímur, or his poetical narrative in Árni's or Jón ólafsson's notes, ${ }^{21}$ indicating that the conception of authorship and authenticity might differ depending on whether the text in question is in verse or prose.

Since rímur are commonly acknowledged as versifications of already existing prose narratives, their writing is primarily considered a craft in the realm of poetical language. Consequently, the rimur poet is regarded as a versifier. This is made explicit in Ármanns rímur: the non-narrative opening section (commonly called mansöngur, i.e. 'love song') of the last ríma contains the information that a páttur of Ármann was supposedly adopted for these rimur because nobody else wanted to use it (rima VIII,7). ${ }^{22}$ No narrative about Ármann survives that is older than the rimur and could therefore have been the one referred to in this pattur. This raises the question of whether an older prose narrative, now lost, once existed or the poet made this up to legitimise his rimur. ${ }^{23}$ Aside from reading this remark as proof of the existence of an older narrative about Ármann, the poet's comments about possible already existing texts appear to be part of a dialogue with the audience about the rimur themselves: in the first rima, the poet parenthetically affirms the existence of Icelandic books that tell of Ármann and his deeds (ríma I,16), implying that Ármann is of great significance, thus transferring that significance to the rimur by association. In the mansöngur of the fifth ríma, it is stated that 'the old narrative about Ármann is solely narrated to pass the time' ("Áfram ber eg / Ármanns páttinn gamla, / stakan til pess að stytta dag, / stundum gleymi eg rauna hag.", ríma V,7) ${ }^{24}$ Here, the poet refers to his own performance and the purpose of his recita-

19 Jón Helgason 1948, p. XXVII.

20 Jón ólafsson úr Grunnavík 2018, pp. $214 f$.

21 Jón ólafsson úr Grunnavík 2018, pp. $217 f$.

22 Jón Helgason 1948, p. XXII; Driscoll 1997, p. 12.

23 In a review of the reprint of the reworked Ármanns saga, Guðbrandur Vigfússon (1859) was one of the first to discuss this issue and doubted the pre-existence of a saga or any written sources. Instead, Guðbrandur assumed that the motifs and themes must have been the offspring of 'superstition' (bábylja) and that 'folk tales' (almúga sögur) about Porsteinn gáli had been used. Jón Helgason 1948, p. 48. 
tion. Beyond that, this stanza also suggests that the 'old narrative about Ármann' is not understood as separable from the poetic interpretation: it is 'the old narrative' which is recited. This again emphasises that the authorship of rimur was primarily associated with the versification of an already existing narrative. It is striking that the benefits of the narrative's transformation into a poetical text are even indicated in AM 128 II 8vo and Lbs 896 4to, which also claim in their niðurlag ('ending') that nobody wants to learn the original páttur.

Whereas all this evidence taken together could suggest the existence of a former narrative, it is also possible that the poet's comments mainly serve as legitimisations for reciting the rimur. They are by no means atypical for this tradition but are found in other rimur as well. These characteristics possibly go back to skaldic poetry and German minne conventions. ${ }^{25}$ In both traditions, the communication between the sender and the receiver is explicit and links the poet to the text: either when a skaldic verse is recited by a character in a saga (e.g. in Egils saga, when Egill as a three-year old recites a stanza about participating in a feast uninvited) or the troubadour addresses his lover in his poem. In both cases, there is a (diegetic) individual who is seen as creatively responsible for the poetic text.

\section{The Author as Impostor}

Even though many sagas contain references to older narratives ('it is told', 'people say'26) or their narrators make themselves noticed in judgemental side comments about the narrative itself (e.g. in Fiðreks saga af Bern), in pre-modern Icelandic prose texts the dialogue between sender and receiver is not yet as explicit as it would later become in the novel. Editorial fiction like the epistolary novel utilises literary devices which provide a framework for emphasising the process of narration and the dynamics of authorship and editorship, broadly comparable to the mansöngvar. Pre-modern prose texts, however, do not share these characteristics, suggesting that the modern, euphemistic conception of the author as individual creator who invents a story from scratch did not yet exist at that time. Moreover, Icelandic manuscripts often lack any information about the authors of texts. There are no indications that contemporaries had a particular interest in authors either, with one exception: to a collector of medieval manuscripts like Árni Magnússon, the text's creator becomes relevant once the prose narrative has been classified as a contemporary forgery and the culprit must be identified.

E.g. 'svo er sagt' in Egils saga or 'svo segja menn' in Laxdœela saga. Ordbog over det norrøne prosasprog. ONP: Dictionary of Old Norse Prose, URL: https://onp.ku.dk (last accessed 1 March 2021). 
In this context, Jón Porláksson's Ármanns saga was not an isolated case but corresponds to a pattern of how recently written sagas and their authorship were evaluated in the $17^{\text {th }}$ and $18^{\text {th }}$ centuries. Árni Magnússon noted about a text usually referred to as Vitlausa Egla ('Silly Saga of Egill'), ${ }^{27}$ a $17^{\text {th }}$-century reworking of the medieval narrative Egils saga, that it was 'different from any other version of Egils saga' he knew ("ölik ỏllum ỏdrum Egils sỏgum"):

Mig minner, eg hafi einhversstadar, epter sỏgu Sigurdar ä Knör, ad hann pessa Egilssỏgu ritad hafi epter hendi lærda Gisla i Melrackadal, og er pä Gisle, öefad, author bokarinar. Gisle var ad vïsu sannreyndr impostor. Enn Sigurdur var frömur madr. ${ }^{28}$

I recollect that I have [a note? S. O.] somewhere, according to the account of Sigurður of Knör, that he wrote this saga of Egil [sic] following the learned Gísli of Melrakkadalur, and consequently Gísli is the undoubted author of the book. Gísli was certainly a blatant impostor. But Sigurður was a[n] honest $\operatorname{man}[.]^{29}$

Although variance and mouvance were by then the rule within Icelandic manuscript culture, this version of Egils saga obviously went too far. This assessment suggests that there was a fine line between minor changes and an entire recast of a saga, which found its expression in Árni's differentiation of the 'honest scribe' Sigurður and the 'faking writer' Gísli. Accordingly, the term "author", which Árni applied in this context, was primarily used to refer to someone who had authority for a text and who, in this case, was thus responsible for this 'forgery'; it however lacked the euphemistic interpretation that emerged in the $19^{\text {th }}$ century. The same conception of the author is reflected in Árni's evaluation of Jón Porláksson's Ármanns saga, where a reference to the author likewise served as a red flag for an unauthentic, forged text.

\section{The Reworked Ármanns saga and the Question of Origin}

It was not until the print of the reworked Ármanns saga in Hrappsey around 1782 that the question of authorship and the sources and backgrounds of the older Ármanns rimur and saga was pursued in depth. In this more verbose reworking, the focus lies on Ármann and his efforts in Iceland, whereas borsteinn only plays a minor role in the last five chapters. As it was published without a title page, contemporaries soon puzzled over

27 I would like to thank Lena Rohrbach for pointing me towards this prose text and the research about it conducted by Svanhildur Óskarsdóttir (2015).

28 On a note in AM 454 4to. Saga af Egli Skallagrímssyni (Vitlausa-Egla), [early $18^{\text {th }}$ century].

29 Svanhildur Óskarsdóttir 2015, p. 194. Punctuation added by M. K. 
its origin and whether it was an 'authentic' saga or a new composition and, if so, who was the culprit.

Only a few years after its publication, Peter Erasmus Müller already included this new Ármanns saga in his 'Sagabibliothek' and concluded from the presence of the character Bárður Dumbsson, who is the protagonist of Bárðar saga Sncefellsáss, that Ármanns saga must have been composed a little later, therefore listing it in the chapter on texts from the $15^{\text {th }}$ century. ${ }^{30}$ Evidently, Müller was neither familiar with Jón loerði's rímur nor the prose version of it by Jón Porláksson. One of the first to point out that it had to be a later narrative adapted from older sources was Jón Espólín Jónsson, who wrote in reaction to Müller's publication that in Iceland, the text was known to be based on an 'older tale' ("ældre Fabel") and written after 1700 by Einar sýslumaður Eyjólfsson. ${ }^{31}$ Some decades later, Konrad Maurer would point out that Jón Espólín was right about the background of the printed text but probably confused the newer saga with the older one and wrongly assumed that, instead of Jón Dorláksson, his contemporary Einar Eyjólfsson († 15 July 1695) had written it. ${ }^{32}$ Einar Bjarnason á Mælifelli, a contemporary of Jón Espólín, attributed the newer Ármanns saga to Jón Jónsson Thorlacius († 1708), stating that this information went back to Hallgrímur Jónsson djákni. ${ }^{33}$ Accepting that the reworked Ármanns saga was written at the end of the $18^{\text {th }}$ century, the newer saga and the older one probably got mixed up again because Jón Thorlacius was the son of Jón porláksson, ${ }^{34}$ who according to Árni Magnússon had written the older páttur. Interestingly, at another point Einar attributed Ármanns rímur to Jón loerði but failed to mention the older Ármanns saga in the entry for Jón borláksson. ${ }^{35}$ That being said, it appears as though in the first half of the $19^{\text {th }}$ century, scarcely anybody was very knowledgeable about the older prose narrative or even aware of the existence of two sagas.

The first to follow up the origin of the tales more systematically was the Icelandic scholar Guðbrandur Vigfússon, who was based in Copenhagen in the 1850s and 1860s and worked in the Arnamagnæan Library. Having access to all Icelandic manuscripts that Árni Magnússon had brought to Denmark over a century ago, Guðbrandur assisted the Icelandic librarian Jón Árnason (who, following in the footsteps of Jacob and Wilhelm Grimm, was at this time preparing a collection of Icelandic folk tales in p. 193. In a footnote, Einar Bjarnason refers to Jón Espólín's article but does not comment on it. See further ÍB 385 4to. Hallgrímur Jónsson: Uppteiknunar Tilraun Skálda og Lærda Manna Islenzkra einkum Rithöfunda, 1835, p. 306.

34 Páll Eggert Ólason 1948-1952, vol. 3, pp. 291 and 315.

35 AM 1055 4to. Einar Bjarnason: Nokkura Skálda oc Rithøfunda eður Fræðimanna Tal á Íslandi, 1838, pp. $115 f$. 
Reykjavík ${ }^{36}$ ) by occasionally looking over manuscripts in the Arnamagnæan Manuscript Collection and checking whether there was anything that Jón could incorporate into his collection. In a letter dated 10 April 1859, Guðbrandur asked Jón for clarification as to what kind of material would be useful for the collection and what was to be done with texts like the new Ármanns saga, which had just been reprinted in Akureyri the year before. Guðbrandur believed the saga to date from the $18^{\text {th }}$ century but to contain some motifs and themes borrowed from older folk tales. He also reported having found the manuscripts of Jón porláksson's páttur and Jón leerði's rímur in the Arnamagnæan Manuscript Collection, which share similarities with the printed texts but are on the whole very different works, and asked Jón Árnason whether he knew of someone in possession of further information on this issue. ${ }^{37}$ Jón responded on 19 June 1859 that he was familiar neither with Ármanns rímur nor the older páttur, indicating that, by this time, neither text was well known in Iceland any longer. He agreed with Guðbrandur that the printed version contained oral tradition but was undecided whether Ármanns saga should be included in his collection or not. And if so, Jón wondered whether this newer tale ought to be listed under the name of Jón prestur porláksson, possibly referring to the popular poet of this name who was active in Hrappsey in the 1780s. ${ }^{38}$ It is likely that Jón Árnason here confused Jón sýslumađur porláksson, the attributed author of the older narrative, with Jón prestur Porláksson because there is no further evidence to support his statement. Jón Árnason eventually concluded that he would probably not use the material..$^{39}$ In a response of 14 July 1859 , Guðbrandur notified Jón that he had finished a review ${ }^{40}$ of the reprint of Ármanns saga, which had been published in Copenhagen, and eventually advised against including Ármanns saga, although he thought it might be worthwhile to investigate some of its motifs. ${ }^{41}$ In subsequent letters, it became evident that Jón could not find anything else on this topic in Iceland and therefore, in agreement with Konrad Maurer, who was also consulted concerning this matter, it was decided that Ármanns saga would not be included in the collection. ${ }^{42}$

Jón Árnason: Íslenzkar bjóðsögur og æfintýri.

37 Summary of a letter (NKS 3010 4to. Guðbrandur Vigfússon to Jón Árnason, 10 April 1859). The letters in question are digitised, and some have been transcribed on: Handrit.is, URL: https:// handrit.is; Einkaskjol.is, URL: https://einkaskjol.is; Bréfasafn Jóns Árnasonar, URL: https://www. jonarnason.is/brefasafn/ (last accessed 1 March 2021) and partially printed in Jón Árnason: Úr fórum Jóns Árnasonar. Jón Helgason 1928, pp. 24, 32, 52, and $57 f$. Bodl. GV Icelandic d. 1. Jón Árnason to Guðbrandur Vigfússon, 19 June 1859.

40 Guðbrandur Vigfússon 1859.

41 NKS 3010 4to. Guðbrandur Vigfússon to Jón Árnason, 14 July 1859.

42 Summary of letters: Lbs 2655 8vo. Jón Árnason to Guðbrandur Vigfússon, 17 September 1859; NKS 3010 4to. Guðbrandur Vigfússon to Jón Árnason, 17 October 1859; Lbs 1056 4to. Jón Árnason to Guðbrandur Vigfússon, 15 November 1859. 


\section{Halldór Jakobsson as the Author of the Reworked Ármanns saga}

As early as summer 1859, Guðbrandur Vigfússon, in his critique of the reprint of Ármanns saga, advocated the necessity of studying these later texts to protect unaware scholars against this saga 'forgery'. ${ }^{43}$ Konrad Maurer would follow Guðbrandur's appeal some years later and write a paper about 'Icelandic Apocrypha' ${ }^{44}$ In it, he described his experience with Jón Árnason, reporting on the difficulties of how to treat the wide range of material submitted during the preparation of Jón's collection. Maurer observed that Icelanders would not simply collect and copy their texts but act as 'writers' ("Schriftsteller") themselves. According to Maurer, this practice was pushed to an extreme when the subject matter in question stemmed from the writer's imagination, confronting the collectors with multiple problems in dealing with this kind of material: "von solchen Männern wird dann aber die Grenze zwischen der eigenen Production und der schlichten Mittheilung der überkommenen Überlieferungen zumeist nicht mit der wünschenswerthen Schärfe festgehalten." ${ }^{5}$ ('People like that do not distinguish between their own productions and the unadorned reproduction of the traditional material as sharply as might be desired.') Based on a manuscript culture of mouvance and variance and a written language that had not changed a lot in the past centuries, Maurer concluded that Icelandic literature was prone to forgery and promoted studying neglected texts to identify those that were literary 'changelings' ("Wechselbälge"). Within the scope of his article, Maurer attempted to carry out his own proposition by discussing contemporary texts, including Ármanns saga. He mostly repeated arguments Guðbrandur had published in his review nine years earlier, however augmenting them. Both agreed that it was probably Halldór Jakobsson (the uncle of Jón Espólín ${ }^{47}$ ) who had written the printed Ármanns saga, something they claimed to have heard in $1859 .^{48}$ To support their speculation, Maurer called attention to the fact that Halldor had connections to the printing press in Hrappsey in the $1780 \mathrm{~s}^{49}$ and that he wrote another saga 'in the old saga style' ("im alten Sagenstile"), which was printed in Leirá in 1804 (Sagan af Gaungu-Hrólfi sem inntók Nordmandiid). ${ }^{50}$ The latter place was where the Icelandic printing press from Hrappsey had been moved to in 1795, initiated by Hið islenska Landsuppfrceðingarfélagið ('the Icelandic Society of the Education of the Nation') under the

Guðbrandur Vigfússon 1859, pp. $135 f$.

Maurer 1868.

Maurer 1868, p. 59.

Maurer 1868, pp. 59-61.

Páll Eggert ólason 1948-1952.

Guðbrandur Vigfússon 1859, p. 133; Maurer 1868, p. 63.

Halldór Jakobsson: Chronologiæ tentamen eður tímatalsregisturságrip.

Halldór Jakobsson: Sagan af Gaungu-Hrólfi sem inntók Nordmandiid. 
direction of Magnús Stephensen (to whom Sagan af Gaungu-Hrólfi sem inntók Nordmandiid is dedicated). ${ }^{51}$ Moreover, it appears that the same printer, a Swede by the name of Magnús Moberg, was responsible for the first print of Ármanns saga ${ }^{52}$ and Sagan af Gaungu-Hrólfi sem inntók Nordmandiid. All of this evidence taken together would support Maurer's and Guðbrandur's speculations, had there not been Halldór Jakobsson's preface in his saga collection of $1789 .^{53}$

Maurer's and Guðbrandur's argumentation falls flat when the saga collection's preface ("formáli") and the introduction ("Lesendum heilsan!") of Sagan af Gaungu-Hrólfi sem inntók Nordmandiid are discussed together. ${ }^{54}$ In the collection's preface, written around seven years after the publication of Ármanns saga, Halldór discussed sagas in terms of their reliability, differentiating between three types: 1) sagas that are made up exclusively for amusement (e.g. Ármanns saga or Bárðar saga Sncefellsáss), 2) sagas that contain some true stories but conflate them with fairy tales and folk tales, making it impossible to tell which is which (e.g. Örvar-Odds saga or Diðreks saga af Bern), 3) sagas that are closest to reliable history (e.g. Ragnars saga loðbrókar, Njáls saga or Snorri Sturluson's chronicles $\left.{ }^{55}\right){ }^{56}$ Maurer possessed this particular saga collection and also mentioned Halldór's preface in his paper. There, however, Maurer discounted its value in support of his argument that Halldór was the author of Ármanns saga, speculating that Halldór listed Ármanns saga under the fictional narratives in the first group of sagas because he probably meant either the older one by Jón porláksson or - and this idea is not really convincing - the reworked one, wittily keeping his own authorship a secret. ${ }^{57}$

If, however, the introduction of Sagan af Göngu-Hrólfi sem inntók Norðmandiið is taken into consideration, one might wonder whether Halldór actually had it in mind to compose a text like the printed Ármanns saga and publish it without a title page or an introduction. In the introduction of Sagan af Gaungu-Hrólfi sem inntók Nordmandiid, Halldór explains that he has seen Göngu-Hrólfur (Rollo) mentioned in other stories but never read an entire story about him, neither in Icelandic nor in any other language. For this very reason, Halldór decided to compose a saga about him, based on historical

51 Jón Helgason 1928, p. 23; also, Stephensen 1808, p. 200.

52 Jón Helgason 1928, p. 24.

53 MS Icelandic 32 4to. Skemtilegur fraasagna fiesiódur af mørgum merkilegum fornkongum hertogum jørlum og høfdingium [...], compilation of sagas, including an introduction by Halldór Jakobsson, 1789.

54 There is also an introduction ("Til Lesarans") in Halldór Jakobsson: Chronologiæ Tentamen edur Tima-Tals Registurs Agrip fraa Upphafe allra skapadra hluta til vorra Daga.

55 Halldór Jakobsson probably refers here to the text usually referred to as Heimskringla. For a discussion of the Icelandic historiographer Snorri Sturluson as its possible author, see in particular the article by Lena Rohrbach in this volume, p. 141-173.

56 Edited text in Hughes 2016, pp. 28-31.

57 Maurer 1868, pp. 71f. 
sources which he recorded in his introduction (e.g. Ólafs Saga Tryggvasonar, Landnámabók). ${ }^{58}$ It is apparent that Halldór attempted to write a saga, both in the sense of 'story' and 'history', that would live up to the proposition he had implicitly conceptualised in the preface to his saga collection fifteen years earlier: this saga was supposed to be as close to reliable history as possible. Considering these reflections, the notion that Halldór should have written and published Ármanns saga, which blends narratives about Icelandic history with folk tales, appears as a little odd..$^{59}$

Another reason why the theory of Halldór Jakobsson as the author of Ármanns saga ought to be reconsidered is the fact that Magnús Stephensen, who was acquainted with Halldór, did not mention him as the author of Ármanns saga in Island $i$ det attende aarhundrede, historisk-politisk skildret (1808). ${ }^{60}$ Magnús on the one hand knew of Halldór Jakobsson's publication printed in Hrappsey, Chronologice Tentamen edur Tima-Tals Registurs Agrip fraa Upphafe allra skapadra hluta til vorra Daga $(1781),{ }^{61}$ on the other hand he mentions that Ármanns saga was printed the same year as Sagan af Egle Skallagrims Syne (1782) in Hrappsey. ${ }^{62}$ If Magnús had known about Halldór's authorship, it might be expected that he would have mentioned him.

As for Konrad Maurer, to return to him once more, he wrongly assumed Sagan af Gaungu-Hrólfi sem inntók Nordmandiid to have been printed in Copenhagen, whereas it was actually printed in Leirá. Furthermore, he mentions that Halldór became sýslumaður, a 'magistrate' of the 'district' of the Vestmannaeyjar in $1757 .{ }^{63}$ It is indeed correct that Halldór was offered Vestmannaeyjasýsla but he never took it up and was instead appointed magistrate of Strandasýsla the year after. ${ }^{64}$ Since the title page of Sagan af Gaungu-Hrólfi sem inntók Nordmandiid gives the correct publishing place and mentions Strandasýsla, it is doubtful that Maurer had the print in front of him while preparing his essay Über isländische Apokrypha. Perhaps Maurer entirely forgot about the preface - because if he had remembered it, he might have come to a different conclusion regarding the authorship of the Ármanns saga printed in Hrappsey. Even though on closer inspection, Konrad Maurer's and Guðbrandur Vigfússon's attribution of Ármanns saga to Halldór Jakobsson is based on questionable evidence, the (unverified) consensus since the early $20^{\text {th }}$ century at the latest has been that it was Halldór Jakobsson who wrote Ármanns saga. ${ }^{65}$

58 Halldór Jakobsson: Sagan af Gaungu-Hrólfi sem inntók Nordmandiid, p. [6].

59 Hughes 2016, p. 29.

60 Stephensen 1808 (originally published in Icelandic: Stephensen 1806).

61 Stephensen 1808, p. 208.

62 Stephensen 1806, p. 511; Stephensen 1808, pp. 169 and 199.

63 Maurer 1868, p. 71.

64 Páll Eggert Ólason 1948-1952, vol. 2, p. 258.

65 E.g. Guðni Jónsson 1947, vol. 12, p. XIII; Páll Eggert Ólason 1948-1952, vol. 2, p. 258; Simek / Hermann Pálsson 2007, p. 18; Hughes 2016, p. 8. 


\section{Transmission and Transformation of the Hrappsey Print}

Guðbrandur Vigfússon's and Konrad Maurer's attribution did, however, not spread immediately: around 1890, amateur historian and scribe Sighvatur Grímsson Borgfirðingur copied various texts for a multi-volume compilation entitled Íslendinga Sögur. Many of his copies, including the reworked Ármanns saga, are accompanied by a preface or postscript ${ }^{66}$ in which he comments on the copied exemplar and the respective saga type. Of Ármanns saga, Sighvatur records that he copied the Hrappsey print but also referred to the reprint from Akureyri. Afterwards, he draws attention to the names of places and persons mentioned in the text in order to discuss the credibility of the saga. According to Ármanns saga, Ármann meets both Ingólfur Árnason (around 874) and Eiríkur Blóðöx (around 930) and was present at Iceland's Christianisation (around 1000), which would imply that Ármann was at least 126 years old at the end of the story. ${ }^{67}$ Sighvatur concludes from these calculations that

[m]ennirnir hafa án efa verið til, en sögu ritarinn, sem hefir verið mörgum öldum síðar[,] hefir farið eptir munnmælum, sem pá hafa verið búnar að fá pjóðsögu blæ miðaldanna[,] sem allur var hneigður að landvættum og afreksverkum hinnar horfnu frægðar aldar. ${ }^{68}$

these people existed without any doubt but the saga writer who lived many centuries later relied on oral tradition which by then had already obtained the characteristics of a medieval folk tale, with a great predilection for landvcettir ('land spirits') and heroic deeds of the vanished glory of the past.

Sighvatur was probably not aware of the research into Ármanns saga conducted by Guðbrandur and Maurer, nor did he share their interest in the question of authorship but was mostly concerned with the question of its verisimilitude.

Over the past few centuries, the reworked Ármanns saga has not only drawn the interest of scholars but also that of poets: at least five rimur cycles were based on the new prose narrative, illustrating its popularity in the $19^{\text {th }}$ century ${ }^{69}$ One of them was composed in 1816 by Magnús Jónsson í Magnússkógum and is preserved in at least nine copies, one of which is an autograph. ${ }^{70}$ Magnús, who is known to have used prints as a basis for his rímur, usually aimed at adopting the entire prose narrative. ${ }^{71}$ Accordingly, the whole plot of Ármanns saga is turned into twelve rímur without omitting a chapter.

See also Driscoll 2013, pp. 57f. about Magnús Jónsson í Tjaldanesi.

Lbs 2330 4to. Íslendinga Sögur, II. Bindi, 1886-1891, fol. 95r-v.

Lbs 2330 4to. Íslendinga Sögur, II. Bindi, 1886-1891, fol. 95v.

Finnur Sigmundsson 1966, vol. 1, pp. 38-41.

Finnur Sigmundsson 1966, vol. 1, p. 38.

Eva María Jónsdóttir 2015, pp. $110 f$. 
Jón Oddsson Hjaltalín, ${ }^{72}$ however, proceeded differently in his rímur, even though he probably used the same print as Magnús: ${ }^{73}$ in his rímur cycle Ármannshróður of 1818 , which is preserved in one autograph, ${ }^{74}$ he transformed only the eponymous part of Ármanns saga and its appendix into seven rimur and excluded the last five chapters about porsteinn and his trials, contending in the seventh rima that the tale of porsteinn was untruthful and had never happened like this. ${ }^{75}$ Jón Hjaltalín's approach confirms the existence of a general sense of insecurity about how this saga should be read: as historical source or fictional literature. But not only rimur were based on the then still new prose narrative; the tale also found its way into a larger and more complex prose text: Eiríkur Laxdal's ólandssaga.

\section{Eiríkur Laxdal. One of Iceland's First Fiction Writers?}

Eiríkur Laxdal Eiríksson, a contemporary of Jón Oddsson Hjaltalín and Magnús Jónsson í Magnússkógum, is known to be the author of two prose texts: ólandssaga and ólafs saga Dórhallasonar. The latter, which is considered by scholars to be quite enjoyable ${ }^{76}$ and seamless, ${ }^{77}$ was eventually edited in $1987 .{ }^{78}$ Ólandssaga, on the other hand, is seen as verbose, fragmented, and pompously moralising. ${ }^{79}$ Consequently, it was not made available in print before 2006 and has largely been overlooked in the past decades. ${ }^{80}$

Both texts have played an important part in the literary history of $19^{\text {th }}$-century Iceland. Both were first read as folk tale collections, and ólafs saga Pórhallasonar in particular has caught the attention of $20^{\text {th }}$-century scholars of literary studies for being an early (proto-)novel in Iceland, even though scholarship has been limited to readings in a historiographical and folkloristic context. ${ }^{81}$ With the exception of Lena

See in particular Driscoll 1997 and his edition of Jón Hjaltalín: Fjórar sögur frá hendi Jóns Oddssonar Hjaltalín (Jón Hjaltalín: Fjórar sögur frá hendi Jóns Oddssonar Hjaltalín). Jón Hjaltalín's wife was probably in possession of the Hrappsey print (Driscoll 1997, pp. 88-90). Finnur Sigmundsson 1966, vol. 1, p. 39. Lbs 248 8vo. Jón Hjaltalín: Rímur eftir Jón pr. Hjaltalín skrifaðar Árið 1826, 1826, fol. 131r: "Enn pad sem umm porstein tér / petta sỏgu letur / syälfsỏgd lýgi sýnist mér / sem eý stadist gétur." (ríma VII, 6, 'And what is said about porsteinn in this story looks like fiction [a lie] to me, which cannot be true.') Einar Ólafur Sveinsson 1940, p. 107; Einar Ólafur Sveinsson 2003, p. 128. Margrét Eggertsdóttir 2006, p. 248.

Eiríkur Laxdal: Saga ólafs Dórhallasonar.

79 Einar Ólafur Sveinsson 1940, p. 104; Einar Ólafur Sveinsson 2003, p. 123.

80 Eiríkur Laxdal: Ólandssaga.

81 E.g. Einar ólafur Sveinsson 1940; Steingrímur J. porsteinsson 1943; Stefán Einarsson 1948; porsteinn Antonsson 2006; Margrét Eggertsdóttir 2006. 
Rohrbach, ${ }^{82}$ only few have made an effort to study the specific literary devices used in both sagas, although such an approach allows for new insights into Iceland's literary production of prose narratives over the last few centuries. The same is true for its conception of authorship: the history of the transmission and early reception of Eiríkur Laxdal's ólandssaga has been outlined, ${ }^{83}$ but its implications for Icelandic literary culture have so far been ignored and will therefore be studied in the remaining paragraphs of this essay.

\section{Adapting Ármanns saga for Ólandssaga}

ólandssaga, of which no autograph has survived, is preserved in one late and fragmented copy (Lbs 554 4to) from the first half of the $19^{\text {th }}$ century. It has been speculated that Eiríkur Laxdal must have started writing the saga in the 1770s because he composed two rímur cycles - Rímur af Hermóði og Hlaðvöru and Rímur af Ingibjörgu alvoenu - in 1777 and 1778, which can be found in ólandssaga as prose narratives and are assumed to have derived from it. ${ }^{84}$ Einar ólafur Sveinsson has speculated that, for his rímur cycles, Eiríkur Laxdal may have reworked a now lost exemplar of ólandssaga which was different than the version that is extant in the fragmental copy, as this would account for some of the differences between the rímur and ólandssaga. For example, in Rímur af Hermóði og Hlaðvöru, Hermóður's father is Hárekur jarl á Skáney and Hlaðvör's parents are Hringur á Borgundarhólmi and Dagmær, whereas in "Hermóðspáttur" in ólandssaga, Hermóður's father is porsteinn Hreiðarsson and Hlaðvör's parents are Hálfdán and Svanhvít. The rímur were probably altered in ólandssaga to genealogically link "Hermóðspáttur" with "Langfeðgapáttur", in which the narrative about Ármann and porsteinn gáli is reworked: in ólandssaga, Hermóður's father porsteinn Hreiðarsson is Porsteinn gáli and Hlað̃ör's father Hálfdán is Ármann / Ármaður (his identity is revealed in chapter 60). Einar ólafur might have been correct in assuming that there was an older ólandssaga on which the rimur were originally based. However, in this former version the different peettir were clearly not connected yet; maybe Eiríkur Laxdal's "Langfeðgapáttur" about Ármann and Dorsteinn did not even exist at that point.

As early as 1940, Einar Ólafur Sveinsson pointed out that chapters 35 to 47 in Ólandssaga, the above-mentioned "Langfeðgapáttur", were based on tales about Ármann and

82 Most recently: Rohrbach 2019a; Rohrbach 2019b. Additionally, the SNF-funded research project 'Romanhaftwerden' at the University of Zurich currently studies $18^{\text {th }}$ - and $19^{\text {th }}$-century Icelandic sagas by Eiríkur Laxdal and his contemporaries: https://www.uzh.ch/cmsssl/ds/de/projekte/ romanhaftwerden.html (last accessed 1 March 2021).

83 porsteinn Antonsson 2006, pp. 7-18.

84 Steingrímur J. Porsteinsson 1943, pp. 186f.; Porsteinn Antonsson 2006, p. 8; Margrét Eggertsdóttir 2006, p. 247. 
porsteinn..$^{85}$ A few years later, Jón Helgason offered an overview of changes made in ólandssaga in comparison with Jón loerđi’s Ármanns rímur. In this overview, Jón explained the differences between both texts by theorising that Eiríkur Laxdal likely did not have the rimur in front of him and consequently overlooked the fact that some motifs and themes probably went back to the $18^{\text {th }}$-century reworking of Ármanns rímur, in addition to which Eiríkur Laxdal's took rather a liberal approach to incorporating the narratives. ${ }^{86}$ The existence of the character King Kálfur in Ólandssaga demonstrates Eiríkur Laxdal's knowledge of the older material, whereas the killing of porsteinn's brothers instead of the slaves and the conflict with porsteinn's father point to the printed one. Eiríkur Laxdal was probably familiar with how the material had been transmitted, and intentionally reworked both strands for his own narrative. This suggests that the "Langfeðgapáttur" was written in the 1780s at the earliest, after the publication of the Hrappsey text.

Aside from changing character names to link different pieces of already existing material, Eiríkur Laxdal deliberately restructured the borrowed narratives, equipped the characters with background stories, and motivated their actions. For example, the character King Kálfur, who is only a minor character in Jón loerði's Ármanns rímur, gains significantly in importance in ólandssaga. The episode of Kálfur originally served as a link between two separate parts in the narrative and above all motivated porsteinn to travel from Iceland to Bjarmaland.$^{87}$ In the Hrappsey print, Kálfur is not even mentioned. In Ólandssaga, however, "Langfeðgapáttur" opens with a chapter about "King Kálfur and his solemn oath' ("Kalfi kóngi og hans heitstrenging"): there, it is said that Kálfur loses his gold panel - in the original tale this happens to his half-sister. In the following chapters, porsteinn returns his father's flock (chs. 36-41) before the episode of Kálfur is eventually taken up again when both meet and porsteinn manages to find Kálfur's gold panel (chs. 42-44). Afterwards, Kálfur sends Dorsteinn to his half-sister Hvít where he must overcome further obstacles to rescue her and her daughter Ingibjörg (chs. 45-47). In Jón leerði's Ármanns rimur, this appears to be a sadistic move by Kálfur to grant Hvít the joy of testing Porsteinn. In ólandssaga, Kálfur's intention to send porsteinn forth seems to stem from his belief that porsteinn is capable of rescuing his sister and niece: “[F]rami pinn mun lítill verða ef pú leggur pig í kyrrsetu far bví og finn Hvít systur mína og vit hvörnin samfundir ykkar verða sé ég pér er lagið framar öðrum mönnum að vinna pér fyrirlagðar prautir mun og svo fara um

85 Einar Ólafur Sveinsson 1929, p. LXXIV; Einar Ólafur Sveinsson 1940, pp. 104-106; Einar Ólafur Sveinsson 2003, pp. 124-127; see also Guðni Jónsson 1947, vol. 12, p. XIII, possibly informed by Einar Ólafur.

86 Jón Helgason 1948, pp. XXXI f.

87 First, Porsteinn finds his father's sheep. Then, Dorsteinn is sold to Kálfur. Afterwards, Kálfur sends porsteinn to his half-sister via Grámann, and there, Porsteinn wins a wife. 
ferð pessa[.]" ('Your advancement will be little if you take a break. Therefore, go and find Hvít, my sister, and see how your encounters will go. I see that you are better than other men at overcoming the tests that are given to you. You will then go on this journey.') What is only hinted at in Kálfur's command becomes evident in the following páttur of Jarðprúður and Hvít, when the reader learns that Hvít and her daughter Ingibjörg have been enchanted by a man named Kári who has also turned Hvít's and Kálfur's brother Hálfdán into Ármann / Ármaður (ch. 60). Kálfur sending porsteinn to Hvít is more than just a link between two episodes; it has an internal motivation: he wants for his family to be free.

Eiríkur Laxdal's liberal handling of the existing material, even though not uncommon in Early Modern Iceland, eventually resulted in confusion among $19^{\text {th }}$-century scholars: how was ólandssaga to be read and which part had Eiríkur Laxdal played in its composition; was he an author, collector, or impostor? This controversy sheds light on the question of the conception of authorship regarding prose narratives.

\section{Writing or Fabricating Stories in Ólandssaga}

Contemporary reference books and the way in which they tend to attribute texts to individuals provide valuable insights into conceptions of the relationship between a text and an individual. Nokkura Skálda oc Rithøfunda eður Frœðimanna Tal á Íslandi is such a reference book of Icelandic literature. Compiled by Einar Bjarnason in the early $19^{\text {th }}$ century, it is equipped with two indices of 'ancient' ("forn") and contemporary poets and several indices of different types of sagas. Out of these, the index with the rather nondescript heading "ímislegar sỏgr flestar mér ókendar" ("various sagas, most of them unknown to me') might be the most promising in regard to the question of authorship: Einar here catalogued highly diverse titles, including Sagan af Esopo, Sagan af Ulises, Sagan af Zadig, Sagan af Ivent, Sagan af Loðinbirni Parmes, and also Sagan afólandi, without, however, mentioning Voltaire, Eiríkur Laxdal, or any other author (except for Sagan af Skanderbeg, which Einar explicitly points out as not having been written by Holberg) ${ }^{89}$

The individuals behind the texts were obviously of little importance for Einar's purposes, and it appears as though these indices were primarily intended to give an overview of all the texts that Einar knew or had heard of, arranged according to genre and in

Eiríkur Laxdal: Ólandssaga, p. 145. Punctuation and capitalisation according to Lbs 554 4to. Eiríkur Laxdal: Ólandssaga, [ca. 1820?], fol. 45v.

89 AM 1055 4to. Einar Bjarnason: Nokkura Skálda oc Rithøfunda eður Fræðimanna Tal á Íslandi, 1838, pp. 40-44. Oddly enough, Eiríkur Laxdal's other text ólafs saga Pórhallasonar is entirely missing in this list, even though Einar Bjarnason eventually attributes both texts to Eiríkur Laxdal. 
alphabetical order. The relationship between individual and text only gains significance when it comes to the portrayal of the poets and authors: texts make individuals memorable. In the section devoted to the person "Eyrikr Laxdal sonr Eyriks", a list of Eiríkur Laxdal's poetical and prose texts is given and ólandssaga and ólafs saga Porhallasonar are eventually attributed to him. Einar writes about the former that it was 'long and completely made up' by Eiríkur Laxdal ("laung ỏll diktuð af hỏnum"); the latter was, in his opinion, 'alike, a large work' ("eins, mikið verk") entirely about elves and hidden people. ${ }^{90}$ No such remark exists about Eiríkur Laxdal's rímur, suggesting that this information was not considered necessary - another reason for this might have been that the term rimur describes a poetic genre whereas the term saga is rather more ambiguous and can refer to both 'story' and 'history'.

Some decades later, this evaluation would resonate in the Prestacevir, in which Sighvatur Grímsson Borgfirðingur ${ }^{91}$ expressed a similar opinion of Eiríkur Laxdal's texts: in his handwritten encyclopaedia, which provides biographical information about Icelandic clergymen who had lived in Iceland, Sighvatur noted that Eiríkur Laxdal 'put together' ("setja saman") folk and fairy tales and wrote something called ólandssaga. It is only subsequently that Eiríkur Laxdal is described as a 'poet' ("skáld") who also "composed' ("yrkja") rimur. ${ }^{92}$ A few years later, Hannes porsteinsson, archivist at the National Archives of Iceland, would repeat and emphasise this evaluation in Ævir loerðra manna, another handwritten biographical encyclopaedia, by saying of Eiríkur Laxdal's ólafs saga Pórhallasonar that Eiríkur Laxdal 'composed or rather: fabricated from his own breast this series of Icelandic folk tales' ("Eiríkur samdi eða réttara sagt laug upp frá eigin brjósti pjóðsagnabálki íslenskum; samsetningur”). ólandssaga was considered the same kind of 'composition' ("samsetning") as Ólafs saga Dórhallasonar. Like the accounts previously discussed, Eiríkur Laxdal's rímur are listed by Hannes but are not judged by the same measure with respect to their composition as his prose narratives. ${ }^{93}$

The fact that all three authors highlight the circumstance that Eiríkur Laxdal 'fabricated', 'put together', and 'wrote' his prose texts but 'poetised' his rimur is perfectly in line with what has been said about Icelandic authorship previously: usually, composing rímur entailed choosing an existing prose narrative and transforming it into verse, partially or entirely; inventing a story and taking responsibility for the content was rarely something a rímur poet was concerned with.

90 AM 1055 4to. Einar Bjarnason: Nokkura Skálda oc Rithøfunda eður Fræðimanna Tal á Íslandi, 1838, pp. $107 f$.

91 Davíð Ólafsson 2008; Sigurður Gylfi Magnússon / Davíð ólafsson 2019.

92 Lbs 2370 II 4to. Sighvatur Grímsson Borgfirðingur: Prestaævir á Íslandi. XIII. Bindi: Húnavatnsprófastsdæmi, 1900-1929, pp. 1732-1735. Curiously, Sighvatur Grímsson Borgfirðingur does not mention Ólafs saga Pórhallasonar, suggesting Ólandssaga might have been a little better known. PÍ KA/1-KA/67. Hannes porsteinsson: Æfir lærðra manna, 1912-1934, no pagination. 


\section{Eiríkur Laxdal as a Failed Folk Tale Collector}

Eiríkur Laxdal's ólandssaga also caught the attention of scholars in the field of folklore studies: over the course of 1859 , while preparing his collection of Icelandic folk tales, Jón Árnason tried to get hold of ólandssaga, which he knew little about at this time, only that it was a large book about elves written by Eiríkur Laxdal. In the spring of 1859, Jón Árnason initially approached his bibliophile colleagues Jón Borgfirðingur Jónsson and Jóhannes Guðmundsson for more information about ólandssaga. ${ }^{94}$ From them, Jón Árnason learned that a copy existed in the possession of the farmer and scribe porsteinn porsteinsson. ${ }^{95}$ This must have seemed like a great opportunity to obtain a collection which possibly recorded folk tales that he could add to his own folk tale collection. Therefore, in the following months, Jón Árnason stayed in touch with Jón Borgfirðingur, who reached out to Porsteinn. In the meantime, Jón had found out that the priest ólafur ólafsson á Hrafsteinsstöðum possessed the autograph and tried to get into contact with him; initially, however, without success. ${ }^{96}$ In October of the same year, Jóhannes Guðmundsson informed Jón Árnason that he had met Porsteinn and learnt that Jón Borgfirðingur had already visited porsteinn in summer, taking the copy of ólandssaga with him. Furthermore, Jóhannes also mentioned that he had had the opportunity to take a look into Porsteinn's manuscripts and confirmed something that Jón Árnason had already heard about Porsteinn: he did not copy accurately. ${ }^{97}$ In autumn, Jón Árnason finally received porsteinn's manuscript of ólandssaga from Jón Borgfirðingur but was not satisfied at all with this copy, as a letter to his namesake in November shows: Eiríkur Laxdal, "sem talinn er hỏfundur hennar af ỏllum[,] logið óttalega inn í munnmælasögurnar í henni, spunnið út úr peim, og ránghermt, og svo er betta Exemplar mjỏg svo rángskrifað af porsteini[.]" (Eiríkur Laxdal "who is said to be the author of the whole saga, lied terribly in oral stories there, spun out of them and twisted them, and in addition, this copy was extremely ill-written by porsteinn.') Jón Árnason saw himself faced with two different problems for his enterprise: on the one hand, there was the 'corrupt' copy by Porsteinn Porsteinsson, and Eiríkur Laxdal's liberal handling of folk stories on the other, which together obscured the folk material in its 'genuine' form that he was seeking. Jón Árnason consequently expressed doubts to his namesake Borgfirðingur that he could use anything of ólandssaga unless he found someone who could provide

94 ÍB 98 fol. a. Jón Árnason to Jón Borgfirðingur Jónsson, 20 March 1859.

95 Summary of letters: ÍB 98 fol. a. Jóhannes Guðmundsson to Jón Árnason, 3 May 1859; Bodl. GV German d. 2. Jón Borgfirðingur Jónsson to Jón Árnason, 19 July 1859.

96 Summary of letters: ÍB 98 fol. a. Jón Árnason to Jón Borgfirðingur Jónsson, 26 September 1859; ÍB 98 fol. a. Jón Árnason to Jón Borgfirðingur Jónsson, 10 November 1859.

97 NKS 3010 4to. Jóhannes Guðmundsson to Jón Árnason, 5 October 1859. See also Driscoll 2013, pp. $54 f$.

98 ÍB 98 fol. a. Jón Árnason to Jón Borgfirðingur Jónsson, 10 November 1859. 
him with tales to compare it with. ${ }^{99}$ This is indeed reminiscent of Jón Árnason's handling of the Ármanns saga material, which he decided not to include in his collection at around the same time. This eventually encouraged Jón to again get into contact with ólafur ólafsson, who answered him in early 1860 . However, it seems that Jón did not receive the autograph before 1862, shortly after the publication of the first volume of Íslenzkar pjóðsögur og œefintýri. ${ }^{100}$

In the end, Jón made no use of ólandssaga in his folk tale collection but still devoted a few words to Eiríkur Laxdal when drafting its preface in the course of $1861 .^{101}$ Even though the similarities to Insel Felsenburg was brought to his attention twice, ${ }^{102}$ Jón stuck to reading Eiríkur Laxdal's texts as one large folk tale compilation that he believed to consist of two parts: ólafs saga Pórhallasonar about elves and ólandssaga about folk tales. Unsurprisingly, Jón came to the conclusion that Eiríkur Laxdal had to be one of Iceland's most recent collectors of folk tales. However, Jón attributed the 'inaccuracy' of the recorded folk tales in ólandssaga to Eiríkur Laxdal being a clever but eccentric poet, drawing a causal connection between his character and the structure of ólandssaga: Eiríkur Laxdal's decision to combine folk tales to form a larger saga made it impossible to distinguish between elements he had composed himself and those that he had borrowed, an approach diametrically opposed to the one chosen by Jón Árnason for his own folk tale collection. ${ }^{103}$ This specific reading of Eiríkur Laxdal's texts suggests that Jón did not view Eiríkur Laxdal as an author like, for example, his contemporary Jón Thoroddsen, who wrote Iceland's 'first' novel, ${ }^{104}$ but (to exaggerate the point slightly) as a failed collector whose personality intervenes with the successful undertaking of preparing a collection. There is no hint that he might have seen Eiríkur Laxdal's texts as a literary composition.

\section{Recent Research and Conclusion}

This assessment is echoed in Einar Ólafur Sveinsson's studies of the 1930s and 1940s, where Eiríkur Laxdal is listed as one of the main sources for Icelandic folk stories in the

99 ÍB 98 fol. a. Jón Árnason to Jón Borgfirðingur Jónsson, 10 November 1859.

100 porsteinn Antonsson 2006, pp. $17 f$.

101 In the first edition of the collection (Guðbrandur Vigfússon / [Jón Árnason] 1862-1864, p. XXIV), the paragraph on Eiríkur Laxdal was included in the main text although intended by Jón Árnason as a footnote (Lbs 528 4to. Jón Árnason: Íslenzkar pjóðsögur og Æfintýri, 1850-1865, fol. 9v, 13v). This was duly amended in the second and third editions.

102 Summary of letters: ÍB 98 fol. a. Jóhannes Guðmundsson to Jón Árnason, 3 May 1859; NKS 3010 4to. Jón Borgfirðingur Jónsson to Jón Árnason, 6 May 1859. Insel Felsenburg had been translated into Icelandic and published a few years before (Schnabel: Felsenborgarsögur).

103 Magnús Grímsson / Jón Árnason 1852, pp. III-VI.

104 Jón Thoroddsen: Piltur og Stúlka. 
$18^{\text {th }}$ century alongside Árni Magnússon and Jón Ólafsson úr Grunnavík. ${ }^{105}$ Whereas Árni Magnússon is praised for having collected thoroughly, accurately, and without introducing any changes, Eiríkur Laxdal is characterised as having done the exact opposite. ${ }^{106}$ Consequently, Einar ólafur decided against incorporating the folk tales of ólandssaga in his Verzeichnis isländischer Märchenvarianten but provided an overview of the borrowed tales in his two publications on Icelandic folk tales. ${ }^{107}$ It becomes apparent there that Einar Ólafur's view on Eiríkur Laxdal and ólandssaga differed slightly from Jón Árnason's. Einar ólafur read ólandssaga not so much as a failed collection but as a literary text based on folk tales constructed by the individual Eiríkur Laxdal, and held Eiríkur Laxdal's 'uninhibited' lifestyle accountable for scenes that he found immoral. ${ }^{108}$

With the exception of Guðni Jónsson and Jón Helgason, who, possibly informed by Einar ólafur, have mentioned ólandssaga in connection with the Ármanns sögur and Ármanns rimurr, ${ }^{109}$ there has not been any further investigation into the 'folk narratives' used by Eiríkur Laxdal. ${ }^{110}$ Instead, in the 1940s and 1950s, literary historians Steingrímur J. porsteinsson and Stefán Einarsson stated that Eiríkur Laxdal wrote Iceland's first novels, even though they admitted that especially ólandssaga had, as I have shown, the greatest impact on folklore studies and scarcely any on Icelandic novel writing. ${ }^{11}$ This idea was picked up again in the late 1980s and gained especial significance for the first text edition of ólandssaga in 2003, primarily as legitimation for the text's publication. Although Eiríkur Laxdal's biography is always mentioned in more recent literary histories, ólandssaga - if discussed at all - is mainly read as a literary product of the Age of Enlightenment. ${ }^{112}$

The material about Ármann and porsteinn on the one hand and Eiríkur Laxdal's ólandssaga on the other plainly exemplifies how concepts of authorship were implicitly reflected in scholarly debates on the nature of these texts. The question whether they were authentic or fake automatically led to a greater attention for the author who was regarded as 'blatant forger' or 'eccentric poet' in contrast to the 'honest scribe' or 'reliable collector'. Especially in cases where the text in question was based on an already existing narrative, this resulted in puzzlement of how to treat the material in terms of including it in or, as Jón Árnason had done it for both Ármanns saga and ólandssaga,

105 Einar Ólafur Sveinsson 1940, p. 99; Einar Ólafur Sveinsson 2003, p. 118.

106 Einar Ólafur Sveinsson 1929, p. LXXII.

107 Einar Ólafur Sveinsson 1929, p. LXXIV; Einar Ólafur Sveinsson 1940, pp. 104f.; Einar Ólafur Sveinsson 2003, pp. 124-127.

108 Einar Ólafur Sveinsson 1929, p. LXXIII; Einar Ólafur Sveinsson 1940, p. 104; Einar Ólafur Sveinsson 2003, p. 124.

109 Guðni Jónsson 1947, vol. 12, p. XIII; Jón Helgason 1948, p. XXXI.

110 For ólafs saga Pórhallasonar see María Anna Porsteinsdóttir 1996.

111 Stefán Einarsson 1957, p. 213; Stefán Einarsson 1961, p. 196.

112 porsteinn Antonsson 2006, p. 10; Margrét Eggertsdóttir 2006, p. 248. 
omitting it from research. Interestingly, these debates mostly concern prose texts and rarely ever poetic texts, suggesting that there was a different conception of authorship - with sagas belonging to the realm of 'histoire' (inventing a story) and rimur to that of 'discours' (versifying it). Studying these mostly neglected texts in greater depth would allow for more insights into the text production of $18^{\text {th }}$ - and $19^{\text {th }}$-century Iceland and generate a better understanding of how this literature is to be contextualised.

\section{Bibliography}

\section{Primary Sources}

Ármanns saga, Akureyri 1858.

Ármanns saga, n.p. [Hrappsey] n.d. [ca. 1782].

Ármanns Rímur eftir Jón Guðmundsson lærða (1637) og Ármanns páttur eftir Jón Porláksson, ed. by Jón Helgason, Copenhagen 1948 (Íslenzk rit síðari alda 1).

Ármanns saga ok porsteins gála, in: Íslendinga sögur, ed. by Guðni Jónsson, vol. 12, Reykjavík 1947, pp. 377-414.

Ármanns saga in yngri, in: Íslendinga sögur, ed. by Guðni Jónsson, vol. 12, Reykjavík 1947, pp. 415-468. Eiríkur Laxdal: Ólandssaga, ed. by Porsteinn Antonsson / María Anna Porsteinsdóttir, Reykjavík 2006.

Eiríkur Laxdal: Saga Ólafs Pórhallasonar. Álfasagan mikla. Skáldsaga frá 18. öld, ed. by Dorsteinn Antonsson / María Anna Porsteinsdóttir, Reykjavík 1987.

Halldór Jakobsson: Chronologiæ Tentamen edur Tima-Tals Registurs Agrip fraa Upphafe allra skapadra hluta til vorra Daga, Hrappsey 1781.

Halldór Jakobsson: Sagan af Gaungu-Hrólfi sem inntók Nordmandiid, Leirárgarðar við Leirá 1804.

Jón Árnason: Íslenzkar bjóðsögur og æfintýri, Reykjavík / Leipzig 1862-1864 (Sögurit 19).

Jón Árnason: Úr fórum Jóns Árnasonar, ed. by Finnur Sigmundsson, Reykjavík 1950.

Jón Hjaltalín: Fjórar sögur frá hendi Jóns Oddssonar Hjaltalín, ed. by Matthew James Driscoll, Reykjavík 2006 (Stofnun Árna Magnússonar á Íslandi. Rit 66).

Jón Thoroddsen: Piltur og Stúlka. Dálítil Frásaga, Copenhagen 1850.

Sagan af Egle Skallagrims Syne, Hrappsey 1782.

Schnabel, Johann Gottfried: Felsenborgarsögur. Eður Æfisögur ýmsra sjófarenda, einkum Alberts Júlíusar, sem var saxneskur að ætt. Ritað á bjóðversku af sonarsyni bróðursonar hans, Eberharð Júlíusi, en snúið af danskri tungu á íslenzka, tr. by Guttormur Guttormsson / Daði Níelsson / Ari Sæmundsson, Akureyri 1854.

\section{Secondary Sources}

Davíð Ólafsson 2008 = Davíð ólafsson: Wordmongers. Post-Medieval Scribal Culture and the Case of Sighvatur Grímsson, PhD Thesis, St. Andrews 2008, URL: http://hdl.handle.net/10023/770 (last accessed 1 March 2021). 
Driscoll 1997 = Driscoll, Matthew James: The Unwashed Children of Eve. The Production, Dissemination and Reception of Popular Literature in Post-Reformation Iceland, Enfield Lock / Middlesex 1997.

Driscoll 2012 = Driscoll, Matthew James: Um gildi gamalla bóka. Magnús Jónsson í Tjaldanesi und das Ende der isländischen Handschriftenkultur, in: Jürg Glauser / Anna Katharina Richter (eds.): Text - Reihe - Transmission. Unfestigkeit als Phänomen skandinavischer Erzählprosa 1500-1800, Tübingen / Basel 2012 (Beiträge zur nordischen Philologie 42), pp. 255-282.

Driscoll 2013 = Driscoll, Matthew James: The Long and Winding Road. Manuscript Culture in Late Pre-Modern Iceland, in: Matthew James Driscoll / Anna Kuismin (eds.): White Fields, Black Seeds. Nordic Literacy Practices in the Long Nineteenth Century, Helsinki 2013 (Studia Fennica Litteraria 7), pp. 50-63.

Einar Ólafur Sveinsson 1929 = Einar Ólafur Sveinsson: Verzeichnis isländischer Märchenvarianten. Mit einer einleitenden Untersuchung, Helsingfors / Leipzig 1929 (Folklore Fellows' Communications 83).

Einar Ólafur Sveinsson 1940 = Einar Ólafur Sveinsson: Um íslenzkar bjóðsögur, Reykjavík 1940.

Einar Ólafur Sveinsson 2003 = Einar Ólafur Sveinsson: The Folk-Stories of Iceland, ed. by Einar G. Pétursson / Anthony Faulkes, tr. by Benedikt S. Benedikz, London 2003 (Viking Society for Northern Research 16) [Originally published in Icelandic, Reykjavík 1940].

Eva María Jónsdóttir 2015 = Eva María Jónsdóttir: "Óðar smiður bó annar fyrr, undan hafi hér gengið." Grettisrímur frá 15., 17. og 19. öld, Master Thesis, Reykjavík 2015, URL: http://hdl.handle. net/1946/22634 (last accessed 1 March 2021).

Finnur Sigmundsson 1966 = Finnur Sigmundsson: Rímnatal, vol. 1, Reykjavík 1966.

Genette 1997 = Genette, Gérard: Palimpsests. Literature in the Second Degree, tr. by Channa Newman / Claude Doubinsky / Gerald Prince, Lincoln / London 1997 (Stages 8) [Originally published in French, Paris 1982].

Guð̋brandur Vigfússon / [Jón Árnason] 1862-1864 = Guðbrandur Vigfússon / [Jón Árnason]: Formáli, in: Íslenzkar bjóðsögur og æfintýri, Reykjavík / Leipzig 1862-1864 (Sögurit 19), pp. V-XXXIII.

Guðbrandur Vigfússon 1859 = Guðbrandur Vigfússon: Ritdómar. II. Ármannssaga kostað hefir Hallgrímr Porsteinsson í Saurbæ, Akreyri 1858, in: Ný félagsrit 19 (1859), pp. 131-136.

Guðni Jónsson 1947 = Guðni Jónsson: Formáli, in: Islendinga sögur, vol. 12, Reykjavík 1947, pp. VIIXIV.

Hughes 2005 = Hughes, Shaun F. D.: Late Secular Poetry, in: Rory McTurk (ed.): A Companion to Old Norse-Icelandic Literature and Culture 2005 (Blackwell Companions to Literature and Culture 31), pp. 205-222.

Hughes 2016 = Hughes, Shaun F. D.: Halldór Jakobsson on Truth and Fiction in the Sagas (1789), in: Gripla 27 (2016), pp. 7-50.

Jón Árnason 1954 = Jón Árnason: Formáli Jóns Árnasonar, in: Íslenzkar pjóðsögur og ævintýri, ed. by Jón Árnason / Árni Böðvarsson / Bjarni Vilhjálmsson, Reykjavík 1954, vol. 1, pp. XVII-XXIII.

Jón Espólín Jónsson 1829 = Jón Espólín Jónsson: Nogle Bemærkninger ved Prof. og Ridder, Dr. P. E. Müllers Saga-Bibliothek, in: Tidsskrift for nordisk Oldkyndighed 2 (1829), pp. 65-99.

Jón Helgason 1928 = Jón Helgason: Hrappseyjarprentsmiðja 1773-1794, Copenhagen 1928 (Safn Fræðafjelagsins um Ísland og Íslendinga 6).

Jón Helgason 1948 = Jón Helgason: Inngangur, in: Ármanns Rímur eftir Jón Guðmundsson lærða (1637) og Ármanns páttur eftir Jón Porláksson, Copenhagen 1948 (Îslenzk rit síðari alda 1), pp. VXXXIV.

Jón Helgason 1980 = Jón Helgason: Athuganir Árna Magnússonar um Fornsögur, in: Gripla 4 (1980), pp. 33-64. 
Jón Ólafsson úr Grunnavík 2018 = Jón Ólafsson úr Grunnavík: Safn til Íslenskrar bókmenntasögu sem skiptist i prjá hluta, ed. by Guðrún Ingólfsdóttir / Pórunn Sigurðardóttir, Reykjavík 2018 (Stofnun Árna Magnússonar á Íslandi. Rit 99).

Magnús Grímsson / Jón Árnason 1852 = Magnús Grímsson / Jón Árnason: Formáli, in: Magnús Grímsson / Jón Árnason (eds.): Íslenzk æfintýri, Reykjavík 1852, pp. III-VI.

Margrét Eggertsdóttir 2006 = Margrét Eggertsdóttir: From Reformation to Enlightenment, in: Daisy L. Neijmann (ed.): A History of Icelandic Literature, Lincoln / London 2006 (Histories of Scandinavian literatures 5), pp. 174-250.

María Anna Porsteinsdóttir 1996 = María Anna Porsteinsdóttir: Tveggja heima sýn. Saga ólafs Pórhallasonar og pjóðsögurnar, Reykjavík 1996 (Studia Islandica 53).

Maurer 1868 = Maurer, Konrad: Über isländische Apokrypha, in: Germania. Vierteljahrsschrift für deutsche Alterthumskunde 13 (1868), pp. 59-76.

Müller 1817-1820 = Müller, Peter Erasmus: Sagabibliothek med Anmærkninger og indledende Afhandlinger, 3 vols., Copenhagen 1817-1820.

Páll Eggert Ólason 1948-1952 = Páll Eggert ólason: Íslenzkar æviskrár frá landnámstímum til ársloka 1940, 6 vols., Reykjavík 1948-1952.

Rohrbach 2019a = Rohrbach, Lena: Challenging Cognition. Metadiegesis and Metalepse in Eiríkur Laxdal's sagas. Paper presented at Novelizations of Scandinavian Prose Literature in the Late Premodern Period. Narratological Approaches, conference organised by Klaus Müller-Wille / Lena Rohrbach, Zurich, 5-6 December 2019.

Rohrbach 2019b = Rohrbach, Lena: Postsaga - Protoroman. Rekonfiguration isländischen Erzählens in der Vormoderne. Keynote at Die Arbeitstagung der Skandinavistik, conference organised by Professur für Skandinavistik der FAU Erlangen, Friedrich-Alexander-Universität Erlangen-Nürnberg, 24-26 September 2019.

Seidel 2014 = Seidel, Katharina: Textvarianz und Textstabilität. Studien zur Transmission der Ívens saga, Erex saga und Parcevals saga, Tübingen 2014 (Beiträge zur nordischen Philologie 56).

Sigurður Gylfi Magnússon / Davíð ólafsson 2019 = Sigurður Gylfi Magnússon / Davíð Ólafsson: Minor Knowledge and Microhistory. Manuscript Culture in the Nineteenth Century, New York / London 2019 (Routledge Studies in Cultural History 47).

Simek / Hermann Pálsson 2007 = Simek, Rudolf / Hermann Pálsson: Lexikon der altnordischen Literatur. Die mittelalterliche Literatur Norwegens und Islands, $2^{\text {nd }}$ rev. ed. Stuttgart 2007.

Stefán Einarsson 1948 = Stefán Einarsson: History of Icelandic Prose Writers. 1800-1940, Ithaca 1948 (Islandica 32/33).

Stefán Einarsson 1957 = Stefán Einarsson: A History of Icelandic Literature, New York 1957.

Stefán Einarsson 1961 = Stefán Einarsson: Íslensk Bókmenntasaga. 1874-1960, Reykjavík 1961.

Stegmann 2017 = Stegmann, Beeke: Árni Magnússon's rearrangement of paper manuscripts, PhD Thesis, Copenhagen 2017, URL: https://curis.ku.dk/ws/files/170143361/Thesis_Beeke_Stegmann_ print_version.pdf (last accessed 1 March 2021).

Stegmann 2018 = Stegmann, Beeke: Note to self and other. Árni Magnússon's note slips in paper manuscripts, in: Matthew James Driscoll (ed.): Care and Conservation of Manuscripts. Proceedings of the sixteenth international seminar held at the University of Copenhagen 13-15 April 2016, Copenhagen 2018, pp. 1-34.

Steingrímur J. Porsteinsson 1943 = Steingrímur J. Porsteinsson: Jón Thoroddsen og skáldsögur hans, Reykjavík 1943.

Stephensen 1806 = Stephensen, Magnús: Eftirmæli átjándu alda, Leirárgörðum við Leirá 1806.

Stephensen 1808 = Stephensen, Magnús: Island i det attende aarhundrede, historisk-politisk skildret, Copenhagen 1808. 
Svanhildur Óskarsdóttir 2015 = Svanhildur Óskarsdóttir: Egil Strikes Again. Textual Variation and the Seventeenth-Century Reworkings of Egil's Saga, in: Laurence de Looze / Jón Karl Helgason / Russell Gilbert Poole / Torfi H. Tulinius (eds.): Egil, the Viking poet. New approaches to Egil's saga, Toronto / Buffalo / London 2015 (Toronto old Norse and Icelandic series 9), pp. 175-196.

\section{Manuscripts}

AM 128 I-III 8vo. Jón lærði Guðmundsson: Rímur af Ármanni. Stofnun Árna Magnússonar í íslenskum fræðum (Iceland, [ca. 1700]).

AM 454 4to. Saga af Egli Skallagrímssyni (Vitlausa-Egla). Stofnun Árna Magnússonar í íslenskum fræðum (Iceland, [early $18^{\text {th }}$ century]).

AM 551 d alfa 4to. Compilation of sagas, including Jón porláksson's Ármanns saga og porsteins gála. Stofnun Árna Magnússonar í íslenskum fræðum (Iceland, [1 $7^{\text {th }}$ century]).

AM 934 4to. Ármanns saga. Stofnun Árna Magnússonar í íslenskum fræðum (Iceland, [ca. 1800]).

AM 1055 4to. Einar Bjarnason: Nokkura Skálda oc Rithøfunda eður Fræðimanna Tal á Íslandi. Stofnun Árna Magnússonar í íslenskum fræðum (Iceland, 1838).

BL Add. 4859 fol. Sagna Flockur Wtlendscra pioda Forkunar frödlegur Af Jmislegumm Annara Landa piödumm framande keisurum kongumm [...] Kostgiæfelega Saman Hendtur yfersenn og endurbættur af Ehrurÿkum og ættgøfugum høfdings manne Magnuse Joonssyne Ad Wigur, peim til frödleiks og skiemmtunar, er pesshättar fornar frasaugur heira vilia. Enn af hans forlage skrifadur Af Joone pördar syne. British Library (Iceland, [1693-1696]).

Bodl. GV German d. 2. Papers of Guðbrandur Vigfússon. Bodleian Libraries (Copenhagen, $\left[19^{\text {th }}\right.$ century]).

Bodl. GV Icelandic d. 1. Papers of Guðbrandur Vigfússon. Bodleian Libraries (Copenhagen, [19 ${ }^{\text {th }}$ century]).

ÍB 45 fol. Compilation of sagas, including Jón Porláksson's Ármanns saga og Porsteins gála. Stofnun Árna Magnússonar í íslenskum fræðum (Iceland, [1735]).

ÍB 76 4to. Compilation of sagas, including Ármanns saga. Landsbókasafn Íslands - Háskólabókasafn (Iceland, [ca. 1800]).

ÍB 98 fol. Sendibréf til Jóns Borgfirðings. Landsbókasafn Íslands - Háskólabókasafn (Iceland, [18481910]).

ÍB 210 4to. Compilation of sagas, including Ármanns saga. Landsbókasafn Íslands - Háskólabókasafn (Iceland, [around 1840]).

ÍB 230 4to. Compilation of sagas, including Ármanns saga. Landsbókasafn Íslands - Háskólabókasafn (Iceland, [18 $8^{\text {th }}$ and $19^{\text {th }}$ centuries $]$ ).

ÍB 307 4to. Compilation of sagas and rímur, including Ármanns saga. Landsbókasafn Íslands Háskólabókasafn (Iceland, 1856).

ÍB 385 4to. Hallgrímur Jónsson: Uppteiknunar Tilraun Skálda og Lærda Manna Islenzkra einkum Rithöfunda. Landsbókasafn Íslands - Háskólabókasafn (Iceland, 1835).

JS 270 8vo. Pessa søgubok ä eg med riettu. Olafur Jóns son ä Bvrfelli i Grimsnese. Compilation of sagas, including Ármanns saga. Landsbókasafn Íslands - Háskólabókasafn (Iceland, 1795-1796).

Lbs 248 8vo. Jón Hjaltalín: Rímur eftir Jón pr. Hjaltalín skrifaðar Árið 1826. Landsbókasafn Íslands Háskólabókasafn (Iceland, 1826).

Lbs 2618 vo. Compilation of sagas and rímur, including Ármanns saga. Landsbókasafn Íslands Háskólabókasafn (Iceland, [ca. 1900]). 
Lbs 528 4to. Jón Árnason: Íslenzkar Đjóð-Sögur og Æfintýri. Landsbókasafn Íslands - Háskólabókasafn (Iceland, 1850-1865).

Lbs 554 4to. Eiríkur Laxdal: Ólandssaga. Landsbókasafn Íslands - Háskólabókasafn (Iceland, [ca. 1820?]).

Lbs 633 fol. Saman safn af Islendskumm Nordskumm sem og ødrumm utannlands historíumm sem brúkast meiga til frodleiks og skemtunar øllumm peim sem lesa edur heira vilia. Landsbókasafn Íslands - Háskólabókasafn (Iceland, 1760).

Lbs 896 4to. Jón lærði Guðmundsson: Rímur af Ármanni. Landsbókasafn Íslands - Háskólabókasafn (Iceland, [late 1760s]).

Lbs 1056 4to. Bréfasafn (Guðbrandur Vigfússon, Jón Árnason et al.). Landsbókasafn Íslands Háskólabókasafn (Reykjavík, [19 $9^{\text {th }}$ century]).

Lbs 1461 4to. Compilation of sagas, including Ármanns saga. Landsbókasafn Íslands - Háskólabókasafn (Iceland, 1826).

Lbs 1756 8vo. Compilation of sagas, including Ármanns saga. Landsbókasafn Íslands - Háskólabókasafn (Iceland, [1 $19^{\text {th }}$ century]).

Lbs 1785 4to. Compilation of sagas, including Ármanns saga. Landsbókasafn Íslands - Háskólabókasafn (Iceland, 1833).

Lbs 2330 4to. Íslendinga Sögur, II. Bindi. Landsbókasafn Íslands - Háskólabókasafn (Iceland, 1886-1891).

Lbs 2370 II 4to. Sighvatur Grímsson Borgfirðingur: Prestaævir á Íslandi. XIII. Bindi: Húnavatnsprófastsdæmi. Landsbókasafn Íslands - Háskólabókasafn (Iceland, 1900-1929).

Lbs 2655 8vo. Bréfasafn (Jón Árnason, Peter Christen Asbjörnsen, L. M. Aubert, Laura Zeitlmann et al.). Landsbókasafn Íslands - Háskólabókasafn (Iceland et al., [19 ${ }^{\text {th }}$ century]).

Lbs 3170 4to. Compilation of sagas and rímur, including Ármanns saga. Landsbókasafn Íslands Háskólabókasafn (Iceland, 1888-1896).

Lbs 3627 4to. Nokkrar Fornmanna Fródlegar Søgur til leifelegrar brúkúnar og sciemtunar samanteknar útgiefnar og uppskrifadar peim til pienustu sem elsca vÿsdóm, góddæme, og gamlan Fródleik [...] s[c]rifadar af Haldore Gudmunds Sini. Compilation of sagas, including Ármanns saga. Landsbókasafn Íslands - Háskólabókasafn (Iceland, [19 ${ }^{\text {th }}$ century]).

Lbs 3910 8vo. Compilation of sagas and rímur, including Ármanns saga. Landsbókasafn Íslands Háskólabókasafn (Iceland, [2 $2^{\text {nd }}$ half of the $19^{\text {th }}$ century]).

Lbs 3946 8vo I. hluti. Sagan af Ármanni Dalmannssyni. Skrifuð af Halldóri Steinssyni. Landsbókasafn Íslands - Háskólabókasafn (Iceland, 1897).

Lbs 3972 8vo. Lítill samanburður. Skrifað hefur Sæmundur Guðmundsson Hrólfstaðahelli. Compilation of sagas, including Ármanns saga. Landsbókasafn Íslands - Háskólabókasafn (Iceland, 1864).

Lbs 4364 8vo. Compilation of sagas, including Ármanns saga. Landsbókasafn Íslands - Háskólabókasafn (Iceland, [ $2^{\text {nd }}$ half of the $19^{\text {th }}$ century]).

Lbs 4655 4to. Compilation of sagas, including Ármanns saga. Landsbókasafn Íslands - Háskólabókasafn (Iceland, 1860-1867).

MS Icelandic 32 4to. Skemtilegur fraasagna fiesiódur af mørgum merkilegum fornkongum hertogum jørlum og høfdingium [...], compilation of sagas, including an introduction by Halldór Jakobsson. Houghton Library, Harvard University (Iceland, 1789).

NKS 1836 4to. Árni Magnússon: Qvædam Excerpta de Monumentis et Historiis Islandicis et eorum Auctoritate. Det Kongelige Bibliotek (Copenhagen, [mid-18 $8^{\text {th }}$ century]).

NKS 3010 4to. Bréfasafn Jóns Árnasonar. Stofnun Árna Magnússonar í íslenskum fræðum (Iceland, $\left[19^{\text {th }}\right.$ century]).

DÍ KA/1-KA/67. Hannes Porsteinsson: Æfir lærðra manna. pjóðskjalasafn Íslands (Reykjavík, 19121934). 